\title{
PENINGKATAN KUALITAS PUBLIKASI MAHASISWA DAN SITASI KARYA ILMIAH DOSEN MELALUI WORKSHOP MANAGEMEN SOFTWARE MENDELEY
}

\author{
Syaharuddin ${ }^{1}$, Vera Mandailina ${ }^{2}$, Dewi Pramita ${ }^{3}$, Rima Rahmaniah $^{4}, \operatorname{Rosada}^{5}$, \\ Habib Ratu Perwira Negara ${ }^{6}$ \\ 1),2),3),4),5)Pendidikan Matematika, Universitas Muhammadiyah Mataram, Indonesia \\ ${ }^{6)}$ Teknik Informatika, Universitas Bumigora Mataram, Indonesia \\ email : syaharuddin.ntb@gmail.com ${ }^{1}$,vrmandailina@gmail.com², dewipramita@ummat.ac.id ${ }^{3}$, \\ rimarahmaniah172@gmail.com ${ }^{4}$,ros_ada84@yahoo.co.id ${ }^{5}$, habib.ratu27@gmail.com ${ }^{6}$
}

\begin{abstract}
Abstrak
Salah satu upaya peningkatan kualitas dan kuantitas publikasi di Indonesia adalah pemerintah mewajibkan setiap lulusan diploma, sarjana bahkan pascasarjana untuk melakukan publikasi ilmiah dari hasil risetnya baik di jurnal nasional maupun internasional. Namun fakta di lapangan kuantitas tidak serta merta diikuti oleh kualitas publikasi ilmiah yang baik. Oleh sebab itu, tujuan dari kegiatan ini adalah meningkatkan kualitas publikasi ilmiah mahasiswa melalui workshop managemen referensi dengan software Mendeley serta proses submission hasil penelitian melalui template yang baik berbasis Open Journal System (OJS). Kegiatan ini telah diikuti oleh 83 mahasiswa bidang pendidikan dari delapan program studi. Workshop dilakukan selama tiga hari dengan metode penyampaian materi oleh instruktur disertai praktik langsung oleh mahasiswa, terakhir dilakukan evaluasi menggunakan teknik observasi dan teknik kuesioner terhadap peningkatan penguasaan materi dan keberhasilan kegiatan. Hasil kegiatan menunjukkan bahwa tingkat pemahaman mahasiswa terhadap materi yang disampaikan mencapai rata-rata sebesar $88,2 \%$. Beberapa kendala seperti lemahnya jaringan internet dan labtop yang tiba-tiba error harus menjadi perhatian lebih lanjut untuk diperbaiki pada kegiatan masa mendatang.
\end{abstract}

Kata kunci: Kualitas Publikasi, Karya Ilmiah, Software Mendeley; Sitasi Dosen

\begin{abstract}
One of the efforts to improve the quality and quantity of publications in Indonesia is that the government requires every diploma, bachelor and even postgraduate graduates to conduct scientific publications from their research results both in national and international journals. But the fact in the field of quantity is not necessarily followed by the quality of good scientific publications. Therefore, the purpose of this activity is to improve the quality of student scientific publications through reference management workshops with Mendeley software and the process of submission of research results through a good template based on the Open Journal System (OJS). This activity has been attended by 83 students in the field of education from eight courses. The workshop was conducted for three days with the method of delivering materials by instructors accompanied by direct practice by students, the last evaluation was carried out using observation techniques and questionnaire techniques to improve material mastery and success of activities. The results showed that the level of students' understanding of the material submitted reached an average of $88.2 \%$. Some constraints such as weak internet network and labtop sudden error should be a further concern to be fixed in future activities.
\end{abstract}

Keywords: Quality Of Publications; Scientific Work; Mendeley Software; Lecturer Citation.

\section{PENDAHULUAN}

Pemerintah Indonesia telah menetapkan bahwa setiap lulusan diploma, sarjana bahkan pascasarjana (magister dan doktoral) wajib melakukan publikasi karya ilmiah hasil penelitiannya (Somantri et al., 2015). Lulusan diploma dan sarjana sekurang-kurangnya diupload ke repositori kampus masing-masing (Ruhiawati et al., 2020), sedangkan untuk pascasarjana harus pulikasi ke jurnal ilmiah baik jurnal nasional terakreditasi maupun jurnal internasional bereputasi (Rizal, 
2017). Kebijakan ini membuat banyak perguruan tinggi mulai membiasakan lulusan diploma dan sarjana untuk belajar secara bertahap tentang publikasi sehingga menjadi mudah dan terbiasa ketika melanjutkan ke jenjang pascasarjana.

Banyak perguruan tinggi yang menetapkan publikasi ilmiah ke jurnal nasional maupun internasional menjadi syarat lulus bagi mahasiswa (Adhikara et al., 2014). Tentu hal ini menjadi pijakan awal yang bagus untuk rekam jejak riset dari mahasiswa dan dosen pembimbing serta reputasi kampus itu sendiri. Di jenjang sarjana, rata-rata luaran yang ditargetkan adalah publikasi ke jurnal nasional terakreditasi Science and Technology Index (SINTA) grade 3 sampai 6, sedangkan di jenjang pascasarjana, rata-rata luaran ditargetkan adalah publikasi ke jurnal nasional terakreditasi SINTA grade 1 atau 2 dan atau jurnal nasional bereputasi terindeks Scopus atau WoS.

Namun tidak semua Perguruan Tinggi (PT) menerapkan kebijakan ini. Masih ada PT yang belum siap baik dari segi kualitas maupun kuantitas. Salah satunya di Universitas Muhammadiyah Mataram. Kebijakan ke arah setiap mahasiswa wajib publikasi masih dalam wacana, namun ada juga beberapa dosen yang sudah menerapkan hal tersebut. Hal ini karena banyak standar persyaratan yang harus dimiliki atau dikuasai baik oleh dosen pembimbing maupun mahasiswa sebelum lebih jauh menerapkan kebijakan ini, diantaranya (1) setiap mahasiswa harus memahami teknik publikasi ilmiah berbasis Open Journal System (OJS), (2) setiap mahasiswa harus memahami teknik menulis hasil penelitian ke template jurnal yang siap di-submit, (3) setiap mahasiswa harus memahami teknik menulis rujukan menggunakan software standar referensi seperti Mendeley, EndNote, Zotero, dan sebagainya, (4) setiap mahasiswa harus memahami tujuan dan manfaat dari publikasi ilmiah untuk jenjang karirnya pasca lulus dari diploma atau sarjana, (5) setiap mahasiswa harus memahami tujuan sitasi karya ilmiah yang relevan dengan penelitiannya (Astuti \& Isharijadi, 2019), (Ansor, 2017), (Ratnasari \& Nurislaminingsih, 2017), (Pardjono et al., 2017), (Prahmana et al., 2016), (Somantri et al., 2015), (Adhikara et al., 2014). Masih banyak syarat yang harus dikuasai agar kebijakan tersebut benar-benar optimal ketika sudah dijalankan atau dijadikan kebijakan internal kampus tersebut.

Upaya yang perlu dilakukan adalah mengenalkan kepada mahasiswa basisdata publikasi ilmiah yang mampu memudahkan penelusuran mahasiswa untuk mencari penelitian-penelitian relevan yang update. Salah satunya adalah software Mendeley. Kosasi (2019) telah melakukan pelatihan kepada 51 mahasiswa dalam menggunakan aplikasi mendeley untuk menulis rujukan dan menyusun daftar pustaka. Disamping itu, dalam meningkatkan softskill mahasiswa dalam menyusun paper ilmiah banyak dilakukan pelatihan yang terkait seperti pelatihan Ms Word dan Mendeley (Setiawan et al., 2019), pelatihan mendeley untuk penulisan referensi (Pahmi et al., 2018), pelatihan mendeley dalam meningkatkan kualitas artikel (Kosasi, 2019), (Rahmawati et al., 2018), pelatihan cara sitasi dengan APA style (Mardin et al., 2020), (Pramiastuti et al., 2020), pelatihan cara membuat daftar pustaka dengan sekali klik dan otomatis (Perdana, 2020), (Sandika et al., 2019), (Agustiana et al., 2018), pengembangan aplikasi JISYM (Mandailina et al., 2017), dan aplikasi DASS (Al Musthafa et al., 2019).

Oleh sebab itu, pentingnya workshop peningkatan kualitas publikasi ilmiah ini perlu dilakukan bagi mahasiswa FKIP Universitas Muhammadiyah Mataram guna memudahkan para mahasiswa dalam menulis hasil penelitian tugas akhir atau skripsi ke template jurnal ilmiah secara online. Salah satu kegiatan penting dalam workshop ini adalah mengajarkan kepada mahasiswa tentang software Mendeley dalam memudahkan menulis rujukan dan menyusun daftar pustaka. Sehingga tujuan yang ingin dicapai dari kegiatan ini adalah (1) mahasiswa memahami cara menulis artikel imliah berdasarkan template jurnal ilmiah, dan (2) mahasiswa memahami cara menulis rujukan dan menyusun daftar pustaka mengunakan software Mendeley. Harapan dari output kegiatan ini nanti adalah meningkatnya jumlah sitasi dosen lingkup Universitas Muhammadiyah Mataram dari publikasi-publikasi karya ilmiah mahasiswa yang sudah terbimbing dengan baik dan benar.

\section{METODE}

Kegiatan ini dilaksanakan selama tiga hari di Fakultas Keguruan dan Ilmu Pendidikan (FKIP) Universitas Muhammadiyah Mataram dengan jumlah mahasiswa tiap kelas sebanyak 27-28 orang, jadi total keseluruhan sebanyak 83 orang. Kegiatan diawali dengan penyampaian materi dan diikuti 
dengan praktik langsung menggunakan laptop masing-masing mahasiswa. Adapun tahapan pelaksanaan sebagai berikut.

1. Pemateri bersama dua orang instruktur menyampaikan materi tentang (a) kebijakan pemerintah dalam hal publikasi karya ilmiah mahasiswa diploma, sarjana, dan pascasarjana; (2) pentingnya software Mendeley dalam menulis referensi ketika menyusun karya ilmiah; (3) dampak positif sitasi dosen terhadap rangking perguruan tinggi sebagai dampak penggunaan software Mendeley; (4) teknik publikasi ilmiah berbasis Open Journal System (OJS).

2. Mahasiswa melakukan register akun ke website Mendeley di www.mendeley.com dilanjutkan instalasi software Mendeley serta melakukan sinkronisasi ke Ms Word di laptop masing-masing.

3. Mahasiswa dibawah bimbingan instruktur melakukan proses sitasi publikasi ilmiah dari penelitian-penelitian relevan di proposal skripsi masing-masing untuk memudahkan menulis daftar pustaka.

4. Pemateri atau instruktur melakukan evaluasi kegiatan. Kegiatan evaluasi dilakukan secara dua metode yakni observasi dan penilaian melalui angket. Metode observasi dilakukan ketika kegiatan praktik berlangsung sehingga pemateri dan instruktur bisa melihat keberhasilan dan kekurangan para peserta. Sedangkan angket yang berisi 5 pertanyaan inti sebarkan via WhatsApp Group pasca kegiatan berlangsung. Adapun indikator yang menjadi pertanyaan yakni (1) pengetahuan tentang publikasi di jurnal ilmiah bermanfaat bagi mahasiswa; (2) software Mendeley bermanfaat bagi mahasiswa dalam menuliskan rujukan/daftar pustaka; (3) tingkat penguasaan mahasiswa dalam menggunakan software Mendeley; (4) tingkat penguasaan mahasiswa dalam melakukan submit artikel berbasis OJS; dan (5) kendala-kendala yang mahasiswa alami saat workshop.

\section{HASIL DAN PEMBAHASAN}

\section{Penyampaian Materi Tentang Publikasi Ilmiah}

Materi yang sudah dirancang sebelumnya disampaikan dengan system diskusi bersama mahasiswa. Artinya, ketika penyampaian materi berlangsung tetap dibangun diskusi bersama peserta untuk memberikan kesempatan kepada mahasiswa bertanya terhadap hal-hal yang belum peserta pahami. Dari hasil observasi, rata-rata peserta memahami materi yang disampaikan dengan baik. Materi publikasi ilmiah mendapat respon yang baik di kalangan peserta. Terlihat dari keyakinan dan optimisme akan melakukan publikasi ilmiah dari hasil riset skripsinya. Karena akan berdampak positif bagi kelanjutan karir ataupun jenjang pendidikan mahasiswa di tahap berikutnya.

\section{Register Akun dan Instalasi Software Mendeley}

Setelah penyampaian materi tentang kebijakan pentingnya publikasi ilmiah, selanjutnya seluruh peserta melakukan instalasi tahap awal untuk mengaitkan software Mendeley ke control panel laptop masing-masing. Setelah berhasil instal tahap awal, selanjutnya mahasiswa melakukan register melalui laman www.mendeley.com. Disini peserta mengisi biodata seperti email, nama, password, dan jenjang pendidikan. Setelah berhasil, maka dilanjutkan dengan login ke software Mendeley menggunakan username (name) dan password yang didaftarkan sebelumnya. Setelah itu, peserta di bawah bimbingan instruktur melakukan instal plugin Ms Word untuk menyambungkan software Mendeley ke Ms Word. Adapun suasana kegiatan instalasi terlihat pada Gambar 1. 


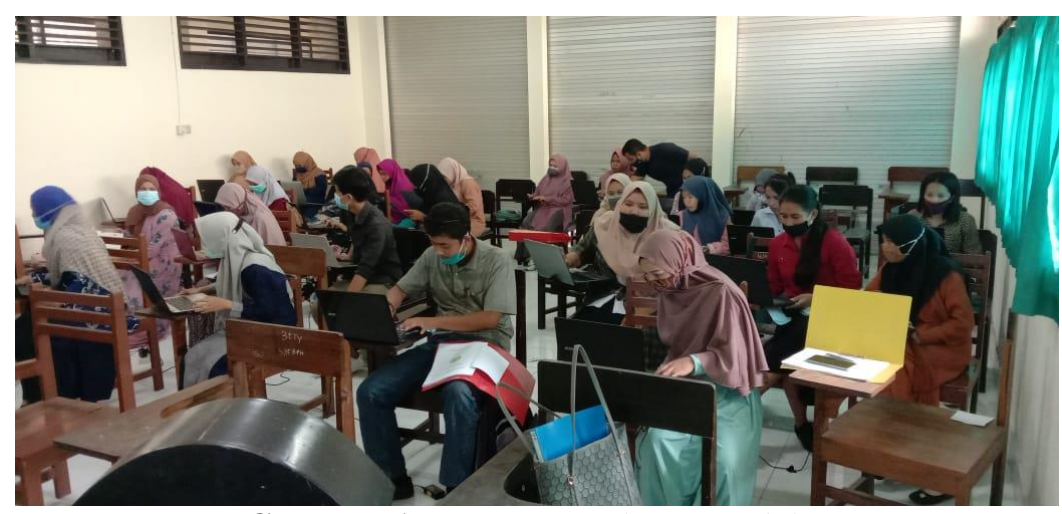

Gambar 1. Proses Instalasi Mendeley

\section{Hasil Sitasi dan Referensi Penelitian Relevan}

Pada tahap ini, peserta diberikan dua pilihan searching yakni melalui Google Scholar dan langsung ke Mendeley. Tahap pertama, peserta mencari hasil-hasil penelitian relevan sesuai variable penelitian masing-masing, kemudian membuat catatan dari judul-judul penelitian tersebut. Selanjutnya, di-insert ke proposal masing-masing melalui tombol search literature di Mendeley. Hal ini dilakukan, karena banyak hasil penelitian yang sudah terpublish di OJS namun tidak terdeteksi di Mendeley.

Selanjutnya, di tahap kedua, mahasiswa langsung mencari penelitian-penelitian revalan melalui tombol search literature Mendeley untuk disitasi dalam proposal skripsi peserta. Proses sitasi ini banyak dilakukan pada bagian pendahuluan (latar belakang), tinjauan pustaka, dan metode penelitian. Setelah peserta selesai menulis semua rujukan, terakhir menyusun daftar pustaka dengan menekan tombol bibliografi Mendeley, selanjutnya tinggal dirapikan (rata kiri-kanan). Target yang ditentukan bahwa jumlah referensi harus minimal 20 artikel baik taraf nasional maupun internasional, terbitan sepuluh tahun terakhir. Sedangkan perbandingan buku dan artikel ilmiah sebesar 80:20.

\section{Hasil Evaluasi Kegiatan}

Evaluasi kegiatan dilakukan menggunakan dua teknik yakni teknik observasi dan teknik angket. Hasil observasi menunjukkan bahwa hampir 96\% mahasiswa telah berhasil melakukan registrasi akun ke www.mendeley.com, instlasi dan mengoperasikan software Mendeley dalam menulis rujukan dan membuat daftar pustaka. Sedangkan menurut hasil angket menunjukkan bahwa secara keseluruhan rata-rata sebesar $88,2 \%$ mahasiswa sudah memahami materi dan teknik membuat daftar pustaka dengan cepat dan baik, hal ini sesuai Tabel 1 berikut.

Tabel 1. Hasil Evaluasi Kegiatan Workshop

\begin{tabular}{clcrcc}
\hline & & \multicolumn{4}{c}{ Item Penilaian (\%) } \\
\hline No & Program Studi & $\mathbf{1}$ & $\mathbf{2}$ & $\mathbf{3}$ & $\mathbf{4}$ \\
\hline 1 & Bahasa Indonesia & 93.7 & 94.7 & 82.1 & 81.1 \\
\hline 2 & Bahasa Inggris & 95.6 & 100.0 & 80.0 & 77.8 \\
\hline 3 & Fisika & 95.0 & 100.0 & 85.0 & 85.0 \\
\hline 4 & Matematika & 93.3 & 100.0 & 86.7 & 80.0 \\
\hline 5 & Geografi & 98.2 & 98.2 & 87.3 & 92.7 \\
\hline 6 & PPKn & 90.0 & 96.7 & 60.0 & 56.7 \\
\hline 7 & PGSD & 97.2 & 95.2 & 86.2 & 81.4 \\
\hline & Rata-rata & $\mathbf{9 4 . 7}$ & $\mathbf{9 7 . 8}$ & $\mathbf{8 1 . 0}$ & $\mathbf{7 9 . 2}$ \\
\hline
\end{tabular}

Dari Tabel 1 juga dapat diketahui bahwa mahasiswa dari Program Studi Geografi memiliki tingkat pemahaman terhadap materi dan praktik membuat daftar pustaka hampir sempurna yakni sebesar $94,1 \%$. Sedangkan program studi paling rendah tingkat pemahamannya yakni PPKn sebesar $75,8 \%$. 
Dari hasil kegiatan yang telah dilakukan terdapat beberapa kendala secara teknis yakni jaringan internet yang kurang mendukung sehingga kecepatan koneksi tidak optimal, laptop tibatiba error yang tidak bisa melanjutkan kegiatan instalasi. Solusi dari permasalahan ini tidak bisa dilakukan secara langsung, perlu dilakukan perbaikan secara bertahap untuk kegiatan-kegiatan berikutnya terutama yang berkaitan dengan jaringan internet, namun sebagai solusi sementara yakni jaringan internet dialihkan ke jaringan hotspot smartphone masing-masing mahasiswa sehingga tidak terpusat ke jaringan wifi kampus.

Pasca kegiatan mahasiswa secara aktif melakukan perbaikan proposal skripsi dengan memperbaiki rujukan dan daftar pustaka. Dukungan dari para dosen pembimbing sangat berdampak positif dalam meningkatkan jumlah sitasi publikasi dosen khususnya pembimbing masing-masing. Dalam masa jangka panjang, tentu ini akan meningkatkan rangking lembaga secara digital.

\section{SIMPULAN}

Hasil kegiatan yang telah dilakukan menunjukkan bahwa rata-rata 88,2\% mahasiswa telah memahami cara menulis artikel ilmiah berdasarkan template jurnal ilmiah, serta memahami cara menulis rujukan dan menyusun daftar pustaka mengunakan software Mendeley. Dampak positif yang terlihat pasca kegiatan dilakukan adalah mahasiswa memperbaiki penulisan rujukan proposal skripsi secara keseluruhan agar proses sitasi dan susunan daftar pustaka terlihat teratur dan konsisten.

\section{SARAN}

Dari kegiatan ini, tim penulis menyarankan mahasiswa tetap melakukan perbaikan-perbaikan pada rujukan yang telah disusun sebelumnya dengan mempertimbangkan hasil-hasil penelitian yang lebih relevan dengan topik riset yang sedang dikerjakan.

\section{UCAPAN TERIMA KASIH}

Tim penulis mengucapkan Terima Kasih kepada Pimpinan Fakultas Keguruan dan Ilmu Pendidikan, UM Matarm yang telah memberikan ijin dan support sehingga kegiatan ini berjalan dengan lancar. Selanjutnya, kepada mahasiswa yang sudah antusias mengikuti kegiatan ini. Semoga dapat diterapkan secara maksimal dalam rangka mengurangi tingkat plagiat pada hasil karya ilmiahnya.

\section{DAFTAR PUSTAKA}

Adhikara, M. A., Handayani, S., Jumono, S., \& Darmansyah, D. (2014). Pelatihan penyusunan artikel publikasi ilmiah pada mahasiswa perguruan tinggi di Jakarta Barat. Jurnal Pengabdian Masyarakat, 1(1), 41-53.

Agustiana, I. G. A. T., Tika, I. N., \& Wibawa, I. M. C. (2018). Pelatihan Membuat Daftar Isi dan Daftar Pustaka dengan Sekali Klik Berbantuan Mendeley Bagi Para Dosen PTS dalam Menyusun Artikel dan Laporan Penelitian Se-Kabupaten Buleleng. International Journal of Community Service Learning, 2(2). https://doi.org/10.23887/ijcsl.v2i2.15540

Al Musthafa, S., Abdillah, A., AK, K. R., Mandailina, V., Pramita, D., \& P.N, H. R. (2019). DASS Application: Increasing the Quality of Academic Services for Lecturers and Students. International Journal of Scientific Research and Management, $7(01)$. https://doi.org/10.18535/ijsrm/v7i1.ec03

Ansor, S. (2017). Studi Meta Analisis Strategi dan Pemanfaatan Jurnal Elektronik (e - journals) untuk Mahasiswa Lulusan Universitas Negeri Malang dalam Upaya Publikasi Ilmiah Bereputasi Internasional. Record and Library Journal, 3(1), 63-73.

Astuti, E., \& Isharijadi, I. (2019). Pengenalan Open Journal System (OJS) untuk Publikasi Ilmiah Mahasiswa. Jurnal Pengabdian Pada Masyarakat, 4(4), 409-414. https://doi.org/10.30653/002.201944.189

Kosasi, S. (2019). Pemanfaatan Aplikasi Mendeley desktop Mengelola Referensi Publikasi Karya Ilmiah Mahasiswa. SNPMas: Seminar Nasional Pengabdian Pada Masyarakat, 64-74.

Mandailina, V., Pn, H. R., \& Ak, K. R. (2017). JISYM : Desktop Application to Increase Lecturer Publication Ratio. International Journal of Innovative Science, Engineering \& Technology, 
4(11), 197-201.

Mardin, H., Baharuddin, B., \& Nane, L. (2020). Pelatihan Cara Menulis Sitasi dan Daftar Pustaka Jurnal Format Apa Style Menggunakan Aplikasi Mendeley. Jurnal Abdidas, 1(3), 137-143. https://doi.org/10.31004/abdidas.v1i3.37

Pahmi, P., Ardiya, A., Syahfutra, W., Wibowo, A. P., Niah, S., \& Febtiningsih, P. (2018). Pelatihan Penggunaan Mendeley Untuk Referensi Dalam Menulis Karya Ilmiah Bagi Guru Sma Handayani Pekanbaru. Jurnal Pengabdian UntukMu NegeRI, 2(2), 35-39. https://doi.org/10.37859/jpumri.v2i2.849

Pardjono, P., Nuchron, N., Surono, S., \& Ramdani, S. D. (2017). Analisis Faktor-Faktor Penghambat Produktivitas Publikasi Karya Ilmiah Mahasiswa PPs UNY pada Jurnal Internasional Terindeks. Jurnal Dinamika Vokasional Teknik Mesin, 2(2), 139. https://doi.org/10.21831/dinamika.v2i2.16002

Perdana, F. J. (2020). Pelatihan Membuat Daftar Pustaka Otomatis Dengan Aplikasi Mendeley Desktop Bagi Mahasiswa Dalam Persiapan Penyusunan Tugas Akhir. Dimasejati: Jurnal Pengabdian Kepada Masyarakat, 2(1), 75. https://doi.org/10.24235/dimasejati.v2i1.6652

Prahmana, R. C. I., Kusumah, Y. S., \& Darhim, D. (2016). Keterampilan Mahasiswa dalam Melakukan Penelitian Pendidikan Matematika melalui Pembelajaran Berbasis Riset. Beta Jurnal Tadris Matematika, 9(1), 1. https://doi.org/10.20414/betajtm.v9i1.8

Pramiastuti, O., Rejeki, D. S., \& Pratiwi, A. (2020). Pengenalan Dan Pelatihan Sitasi Karya Ilmiah Menggunakan Aplikasi Mendeley. Jurnal Abdimas Bhakti Indonesia, 1(1), 24-30.

Rahmawati, C., Meliyana, M., Yuliana, Y., \& Zain, H. (2018). Pelatihan Software Mendeley Dalam Peningkatan Kualitas Artikel Ilmiah Bagi Dosen. Jurnal Pengabdian Kepada Masyarakat, 8(1), 30. https://doi.org/10.30999/jpkm.v8i1.200

Ratnasari, G., \& Nurislaminingsih, R. (2017). Pengaruh Kebijakan Publikasi Karya Ilmiah Di EJournal Terhadap Peningkatan Motivasi Menulis Karya Ilmiah Mahasiswa Ilmu Perpustakaan Fakultas Ilmu Budaya Universitas Diponegoro Semarang Tahun 2009. Jurnal Ilmu Perpustakaan, 6(1), 201-210.

Rizal, A. S. (2017). Sistem Informasi Perpustakaan Repository pada Universitas Islam Negeri Alauddin Makassar Berbasis Web. Sistem Informasi Perpustakaan Repository Pada Universitas Islam Negeri Alauddin Makassar Berbasis Web.

Ruhiawati, I. Y., Gunawan, W., \& Faniya, N. (2020). Aplikasi Repository Pada Perpustakaan Universitas Banten Jaya. Jurnal Sistem Informasi Dan Informatika (Simika), 3(2), 110-126. https://doi.org/10.47080/simika.v3i2.1012

Sandika, I. K. B., Saputra, I. N., Wijaya, W., \& Pratama, I. P. A. (2019). Pelatihan Aplikasi Microsoft Word Dan Mendeley untuk Membuat Daftar Isi dan Daftar Pustaka Otomatis Bagi Guru di SMA Negeri 1 Kuta Selatan. Jurnal Ilmiah Populer Widyabhakti, 1(2), 42-46.

Setiawan, D., Hamzah, H., \& Arlenny, A. (2019). Pelatihan Ms.Word \& Mendeley Untuk Penulisan Karya Ilmiah Dosen Fakultas Teknik Unilak. Dinamisia: Jurnal Pengabdian Kepada Masyarakat, 3(1). https://doi.org/10.31849/dinamisia.v3i1.2215

Somantri, A., Agustin, R. D., Majapahit, S. A., Hexagraha, A., Informatika, T., Pasundan, U., \& Organisasi, K. (2015). Pengukuran Kesiapan Perguruan Tinggi Untuk Mempublikasikan Hasil Karya Ilmiah Internal Civitas Akademika Secara Online. Jurnal Ilmiah Teknologi Informasi Terapan, II(1), 69-75. 